\title{
Study on wear characteristics of tractor drawn rotavator blade of different steel materials
}

\section{K. Aravinda Yadav and Ajay K. Sharma}

Received : 18.02.2020; Revised : 02.08.2020; Accepted : 01.09.2020

See end of the Paper for authors' affiliation Correspondence to : K. Aravinda Yadav Department of Farm Machinery and Power Engineering, College of Technology and Engineering (MPUAT), Udaipur (Rajasthan) India

Email: arvindyadav.k@gmail. com
-ABSTRACT : A rotavator is popularly used to reduce the amount of time and labour spent in field preparation. However, wear of rotavator blades is very high, especially in sandy soil, which significantly affects its working life. The wear test of selected rotavator blades were conducted in circular soil bin made up of different steel materials like medium carbon steel $\left(\mathrm{M}_{1}\right)$, high carbon steel $\left(\mathrm{M}_{2}\right)$ and boron steel $\left(\mathrm{M}_{3}\right)$ to observe the effect of different steel materials on wear. The wear rate of $M_{1}$ blade, $M_{2}$ blade and $M_{3}$ blade were $26.36,24.96$ and $24.05 \mathrm{mg} / \mathrm{min}$, respectively. The boron steel blade was found having maximum hardness $41.8 \mathrm{Rc}$ followed by high carbon steel blade (41.3 Rc) and medium carbon steel blade (39.9 Rc).

- KEY WORDS : Rotavator blade, Steel material, Wear test, Hardness of blade

- HOW TO CITE THIS PAPER : Aravinda Yadav, K. and Sharma, Ajay K. (2020). Study on wear characteristics of tractor drawn rotavator blade of different steel materials. Internat. J. Agric. Engg., 13(2) : 155-159, DOI: 10.15740/HAS/IJAE/13.2/155-159. Copyright@2020: Hind AgriHorticultural Society. 